\title{
Pemanfaatan Konseling Gizi terhadap Perubahan Profil Lipid Pasien Penyakit Jantung Koroner
}

\section{Agus Hendra Al Rahmad ${ }^{\mathrm{I}}$}

${ }^{1}$ Jurusan Gizi, Politeknik Kesehatan Kemenkes Aceh, Jl. Soekarno-Hatta Kampus Terpadu Poltekkes Aceh, Lampeunerut, Aceh Besar, 23352, Provinsi Aceh, Indonesia, email: agus.hendra.alr@poltekkesaceh.ac.id

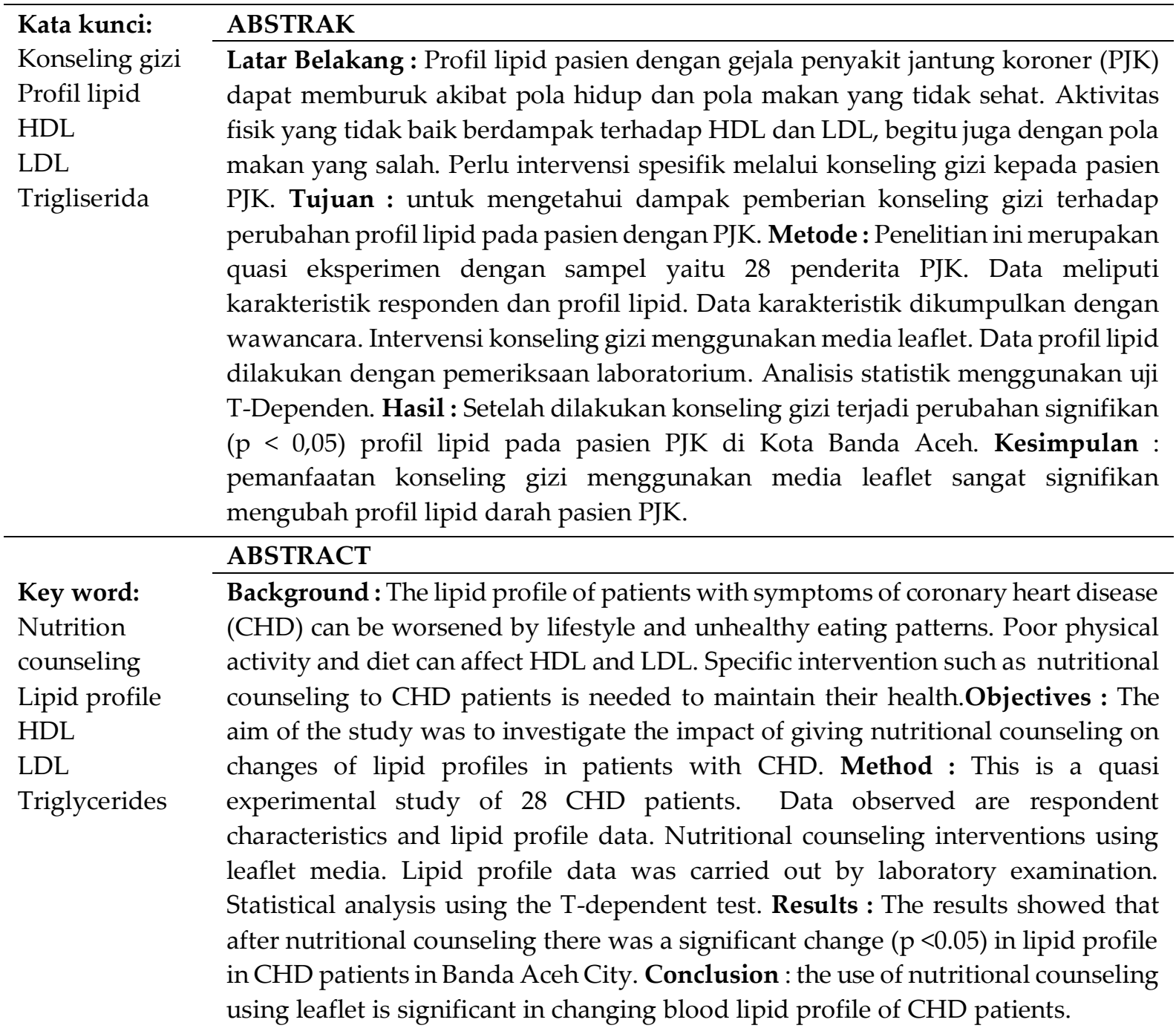




\section{Pendahuluan}

World Health Organization (WHO) pada tahun 2015 telah mencatat secara proporsional bahwa sekitar 31,43\% dari kematian global, terdapat lebih dari 7,4 juta orang meninggal akibat Penyakit Jantung Koroner (PJK) ${ }^{[1]}$. Penyakit jantung koroner masih merupakan penyebab kematian dan kesakitan utama yang berdampak secara sosial ekonomi ${ }^{[2]}$. Kondisi ini akan terus bertambah setiap tahun menjadi 9,4 juta kematian, dan diperkirakan angka tersebut akan meningkat hingga 23,3 juta pada tahun $2030^{[3]}$.

Salah satu faktor resiko terjadinya PJK adalah asupan lemak yang berlebihan ${ }^{[4]}$. Berdasarkan penemuan Pathobiological Determinants of Atherosclerosis in Youth (PDAY) suatu otopsi dilakukan pada pria dan wanita usia 15-34 tahun yang kematiannya tidak disebabkan oleh penyakit kardiovaskuler, menunjukkan bahwa non-HDL dikaitkan dengan adanya tingkat lipid di arteri koroner, lapisan lemak, penonjolan lesi dan stenosis koroner ${ }^{[5]}$. Faktor risiko independen yang memodifikasi proses inflamasi vaskular kompleks dan kronis ${ }^{[6]}$, yang akhirnya bermanifestasi sebagai penyebab yaitu riwayat keluarga penyakit jantung koroner, merokok, diabetes mellitus, hipertensi, hiperlipidemia, gaya hidup, dan obesitas ${ }^{[7]}$.

Jika seseorang kurang melakukan aktivitas fisik tetapi mengkonsumsi makanan yang sangat berlebih, maka dapat meningkatkan LDL (Low Density Lipoproteins) dan menurunkan HDL (High Density Lipoprotein). Tubuh banyak bergerak akan menyebabkan lemak tidak menumpuk dalam tubuh sehingga dapat menurunkan kadar kolesterol. Latihan fisik selama 30 menit sehari dapat menurunkan kadar kolesterol seperti LDL dan meningkatkan HDL ${ }^{[8]}$. Konsumsi karbohidrat yang berlebihan dapat memicu penyakit jantung pada seseorang. Asupan karbohidrat berlebih bisa meningkatkan kadar glukosa di dalam darah dan berakibat pada resiko penyakit jantung yang semakin tinggi. Konsumsi tinggi karbohidrat cenderung meningkatkan kadar trigliserida dan menurunkan kadar kolesterol HDL[9].

Pola hidup seperti aktivitas fisik yang tidak baik berdampak dan berpengaruh terhadap kualitas kesehatan individu apalagi pada usia diatas 30 tahun ${ }^{[10]}$. Begitu juga dengan pola makan yang tidak sehat berpengaruh signifikan terhadap kadar lipid dalam darah seperti HDL, LDL, kolesterol serta trigleserida ${ }^{[11]}$. Kemajuan teknologi serta meningkatnya tingkat sosial ekonomi telah mengakibatkan perubahan pola makan dari pola makan tradisional ke pola makan barat seperti makanan cepat saji dan lemak berkalori tinggi sehingga berdampak pada tingginya prevalensi hiperkolesterolemia di masyarakat ${ }^{[12]}$. Salah satu upaya untuk mengurangi profil lipid yaitu melalui intervensi spesifik kepada penderita jantung koroner pada instalasi gizi rumah sakit. Pendidikan gizi melalui konseling sangat baik dalam meningkat perilaku seseorang[13]. Konseling gizi adalah proses kegiatan secara dua arah yang bertujuan untuk meningkatkan perilaku pasien sehingga dapat mengatasi masalah kesehatan dan gizi, yang umumnya dalam pelaksanaan konseling menggunakan berbagai macam media ${ }^{[14]}$, salah satunya media leaflet. Media Leaflet lebih efektif dibandingkan beberapa media lain ${ }^{[12]}$. Oleh karena itu, penelitian ini bertujuan untuk mengetahui pengaruh konseling gizi dengan leaflet terhadap perubahan profil lipid penderita jantung koroner.

\section{Metode}

Penelitian ini merupakan quasi eksperimen dengan rancangan evaluasi dengan pretest and posttest non-equivalent group, yang melibatkan sasaran yaitu pasien PJK rawat jalan, yaitu sebanyak 28 orang yang diambil secara non-random assignment. Penelitian telah dilaksanakan 
pada beberapa Rumah Sakit di Kota Banda Aceh. Pada kelompok penelitian (sampel) diberikan konseling gizi sebgaai bentuk intervensi spesiefik menggunakan media leaflet bermateri tentang Pencegahan dan Pengendalian PJK. Konseling yang dilakukan dalam penelitian ini selama satu kali dalam semingu. Waktu penelitian berlangsung selama 3 bulan yaitu Februari - April tahun 2019.

Data dalam penelitian ini dikumpulkan melalui wawancara langsung dengan responden dan pemeriksaan laboratorium. Data yang dikumpulkan dengan wawancara yaitu meliputi data karakteristik responden (umur, jenis kelamin, pendidikan dan pekerjaan), data profil lipid yang meliputi kadar kolesterol, HDL, LDL, dan trigleserida diperoleh melalui pemeriksaan laboratorium yaitu Laboratorium Kesehatan Daerah (Labkesda) Provinsi Aceh, dilakukan antara sebelum dengan setelah pemberian konseling gizi. Konseling gizi pada responden PJK dilakukan secara tatap muka menggunakan alat bantu leaflet Penyakit Jantung Koroner (PJK), yang berisi tentang fakta, upaya pencegahan, tanda dan gejala, faktor risiko dan siklus PJK. Konseling dilakukan oleh konselor dari Ahli Gizi Rumah Sakit setempat sebanyak 3 orang, dengan syarat telah mengikuti pelatihan dan edukasi pendidikan gizi. Konseling gizi dilakukan pada ruang khusus di masing-masing rumah sakit, dengan durasi konseling yaitu antara 15-20 menit.

Pengujian pra-syarat analisis menggunakan uji Kolmogorov Smirnov diperoleh bahwa data profil lipid darah (kadar kolesterol, HDL, LDL, dan Trigliserida) telah berdistribusi normal (pvalue $>0,05)$, pengujian normalitas dilakukan pada data profil lipid darah baik sebelum maupun setelah diberikan konseling. Selanjutnya untuk menemukan jawaban dari tujuan penelitian dan membuktikan hipotesis yang diajukan, maka dilakukan analisis statistik yaitu dependent T-test untuk mengukur pengaruh konseling terhadap perubahan profil lipid penderita jantung koroner. Surat layak etik didapatkan dari Komisi Etik Penelitian Kesehatan Fakultas Keperawatan Universitas Sumatera Utara Nomor 1674/II.SP/2019.

\section{Hasil Dan Pembahasan}

Karakteristik Pasien Penyakit Jantung Koroner

Tabel 1. Karakteristik Responden

\begin{tabular}{|c|c|c|c|c|c|c|}
\hline \multirow{2}{*}{$\begin{array}{c}\text { Karakteristik } \\
\text { Responden }\end{array}$} & \multirow{2}{*}{$\mathrm{f}$} & \multirow{2}{*}{$\%$} & \multicolumn{4}{|c|}{ Rerata Profil Lipid } \\
\hline & & & Kolesterol & HDL & LDL & Trigliserida \\
\hline \multicolumn{7}{|l|}{ Usia } \\
\hline $40-59$ tahun & 20 & 71,4 & 260,2 & 65,9 & 159,5 & 180,5 \\
\hline 60 tahun keatas & 8 & 28,6 & 259,7 & 62,3 & 150,1 & 169,4 \\
\hline \multicolumn{7}{|l|}{ Jenis Kelamin } \\
\hline Laki-laki & 11 & 39,3 & 249,7 & 68,0 & 155,0 & 165,0 \\
\hline Perempuan & 17 & 60,7 & 265,5 & 58,4 & 162,2 & 189,8 \\
\hline \multicolumn{7}{|l|}{ Pendidikan } \\
\hline Rendah & 5 & 17,9 & 240,0 & 63,2 & 140,5 & 161,3 \\
\hline Menengah & 10 & 35,7 & 255,2 & 60,5 & 149,7 & 155,8 \\
\hline Tinggi & 13 & 46,4 & 258,7 & 56,0 & 175,5 & 180,0 \\
\hline \multicolumn{7}{|l|}{ Pekerjaan } \\
\hline PNS & 8 & 28,6 & 260,8 & 52,5 & 160,5 & 182,0 \\
\hline Swasta & 5 & 17,9 & 241,5 & 70,0 & 149,3 & 150,0 \\
\hline Wiraswasta & 6 & 21,4 & 253,0 & 55,1 & 158,4 & 170,6 \\
\hline Tidak bekerja & 9 & 32,1 & 250,5 & 59,6 & 154,0 & 156,5 \\
\hline
\end{tabular}


Secara umum distribusi responden lebih banyak berusia antara 40 - 59 tahun yaitu sebesar $71,4 \%$ dan lebih didominasi oleh perempuan (60,7\%). Selain itu, berdasarkan pendidikan terdapat sebesar $46,4 \%$ adalah tinggi dengan pekerjaan yang bervariasi yaitu responden tidak bekerja lebih banyak dibandingkan yang PNS, swasta maupun wiraswasta.

Peningkatan kadar profil lipid darah sangat erat hubungannya dengan aterosklerosis, terutama pada usia 35-45 tahun. Jika kadar kolesterol total dalam darah mencapai $260 \mathrm{mg} / \mathrm{dl}$ maka angka kejadian aterosklerosis akan meningkat 3-5 kali lipat ${ }^{[15]}$. Selain itu, profil lipid darah lebih berisiko meningkat pada wanita usia diatas 40 tahun, dan beberapa faktor lain seperti usia serta riwayat keluarga ${ }^{[16]}$. Namun pendidikan juga sangat berkaitan dengan profil lipid, beberapa studi telah menunjukkan bahwa tingkat pendidikan berdampak terhadap profil lipid darah ${ }^{[9]}$. Responden yang mempunyai tingkat pendidikan rendah cenderung memiliki kadar kolesterol lebih tinggi dibandingkan responden dengan tingkat pendidikan tinggi. Sebaliknya, kadar HDL lebih rendah pada responden dengan pendidikan tinggi ${ }^{[17]}$. Faktor pekerjaan menyumbang lebih besar sebagai faktor risiko[18]. Pekerjaan sebagai faktor tidak langsung terhadap meningkatnya penyakit tidak menular, salah satunya yaitu PJK[17]. Pekerjaan yang lebih baik memungkinkan perubahan gaya hidup seperti kurangnya aktivitas fisik dan cenderung mengkonsumsi makan cepat saji[19]. Masyarakat yang tinggal pada daerah kota memungkinkan pasien mempunyai pekerjaan serta pendapatan yang lebih baik sehingga risiko terhadap penyakit kardiovaskuler lebih tinggi ${ }^{[10]}$.

\section{Pengaruh Konseling Gizi terhadap Perubahan Profil Lipid PJK}

Konseling gizi menggunakan media leaflet telah dilakukan pada 28 pasien rawat jalan yang menderita PJK. Media leaflet yang digunakan dalam konseling memberikan materi terkait Pencegahan dan Pengendalian Penyakit Jantung Koroner (PJK). Dari Tabel 2 diketahui bahwa sebelum diberikan konseling gizi, rerata profil lipid seperti kadar kolesterol sebesar 245,6 mg/dl dengan kadar HDL sebesar 61,5 mg/dl dan LDL sebesar 155,6 mg/dl. Selain itu kadar trigliserida sebelum intervensi sebesar 130,2 $\mathrm{mg} / \mathrm{dl}$. Selanjutnya setelah dilakukan intervensi berupa konseling gizi terdapat perubahan kadar kolesterol menjadi 210,8 mg/dl dengan HDL menjadi $68,4 \mathrm{mg} / \mathrm{dl}$ dan LDL menjadi 130,2 mg/dl. Perubahan kadar trigliserida juga menurun menjadi sebesar $148,5 \mathrm{mg} / \mathrm{dl}$.

Tabel 2. Profil lipid responden PJK antara Sebelum dengan Setelah Konseling Gizi

\begin{tabular}{|c|c|c|c|c|c|}
\hline Kadar Profil Lipid & Min - Mak & Rerata \pm SD & $\begin{array}{c}\text { Selisih } \\
\text { Rerata } \pm \text { SD }\end{array}$ & IK 95\% & Nilai $p$ \\
\hline \multicolumn{6}{|l|}{ Kadar Kolesterol } \\
\hline Sebelum (mg/dl) & $180,0-380,0$ & $245,6 \pm 20,48$ & $34,8 \pm 6,88$ & 18,2 s.d 38,5 & 0,000 \\
\hline Setelah (mg/dl) & $150,0-300,0$ & $210,8+13,60$ & & & \\
\hline \multicolumn{6}{|l|}{ Kadar HDL } \\
\hline Sebelum (mg/dl) & $40,0-75,0$ & $61,5 \pm 9,72$ & $6,9 \pm 2,22$ & 4,0 s.d 10,64 & 0,028 \\
\hline Setelah (mg/dl) & $50,0-82,0$ & $68,4 \pm 7,50$ & & & \\
\hline \multicolumn{6}{|l|}{ Kadar LDL } \\
\hline Sebelum (mg/dl) & $130,0-195,0$ & $155,6 \pm 15,39$ & $25,4 \pm 8,82$ & 15,70 s.d 31,0 & 0,000 \\
\hline Setelah $(\mathrm{mg} / \mathrm{dl})$ & $105,0-150,0$ & $130,2 \pm 10,57$ & & & \\
\hline \multicolumn{6}{|l|}{ Kadar Trigliserida } \\
\hline Sebelum (mg/dl) & $140,0-220,0$ & $160,8 \pm 25,04$ & $12,3 \pm 6,49$ & 9,5 s.d 15,68 & 0,003 \\
\hline Setelah $(\mathrm{mg} / \mathrm{dl})$ & $125,0-200,0$ & $148,5 \pm 18,55$ & & & \\
\hline
\end{tabular}


Diketahui bahwa intervensi konseling gizi dapat menurunkan kadar kolesterol, kadar LDL dan trigliserida, serta meningkatkan nilai HDL. Lebih lanjut membuktikan bahwa hasil uji statistik pada semua profil lipid (kadar kolesterol, kadar HDL dan LDL, serta kadar trigliserida) antara sebelum dengan setelah diberikan konseling gizi dapat berubah secara signifikan (nilai $\mathrm{p}<0,05$ ). Hal tersebut menunjukkan, intervensi berupa konseling gizi menggunakan media leaflet mempunyai manfaat yang signifikan dalam menurunkan kadar kolesterol, LDL dan kadar trigliserida, serta dapat meningkatkan kadar HDL pada pasien PJK rawat jalan di Kota Banda Aceh.

Intervensi berupa konseling gizi menggunakan media leaflet mempunyai manfaat dalam menurunkan nilai kolesterol pasien PJK ${ }^{[12]}$. Perubahan pola hidup serta perubahan asupan nilai gizi pada pasien hiperkolesterolemia yaitu hasil dari pemberian konseling gizi di rumah sakit ${ }^{[20]}$. Intervensi secara spesifik dengan konseling gizi dapat meningkatkan pemahaman serta pola aktivitas pasien yang mendapat promosi kesehatan melalui berbagai konseling menjadi lebih baik $^{[21]}$. Secara individu intervensi melalui konseling gizi dapat mengubah pola hidup serta perubahan pola makan. Hal ini penting untuk penyedia pelayanan kesehatan seperti rumah sakit. Upaya-upaya yang bersifat edukasi sangat penting didukung baik dengan pelaksanaan non-farmakologi (Therapeutic Lifestyle Changes) serta melalui penggunaan dan pemakaian jenis obat-obatan ${ }^{[22]}$.

Konseling gizi yang diberikan melalui media leaflet terdapat materi seperti pola makan/asupan gizi serta aktivitas fisik. Leaflet dengan materi yang sesuai sasaran serta mempunyai cara penyampaian yang baik, maka sangat efektif dalam keberhasilan konseling gizi yang dilakukan oleh konselor ${ }^{[23]}$. Pola makan seperti asupan karbohidrat dan lemak sangat penting diperhatikan sesuai aturan konsumsi seperti porsi dan frekuensi makan. Penyakit Jantung Koroner (PJK) terjadi akibat ketidakseimbangan profil lipid (kolesterol total, LDL, HDL, dan trigliserida) dalam darah. Faktor penyebab yaitu asupan dari makanan serta minuman yang secara berlebihan ${ }^{[9]}$.

Konsumsi karbohidrat serta lemak secara berlebihan merupakan penyebab meningkatkan asetil-KoA yang diperoleh dari proses dekarboksilasi fosforilasi, sehingga peningkatannya membentuk kadar kolesterol secara kompleks ${ }^{[24]}$. Konsumsi karbohidrat secara berlebihan akan meningkatkan gula darah serta meningkatkan insulin. Proses kerja insulin yaitu memindahkan gula darah ke dalam sel dan diubah membentuk glikogen dan energi. Kelebihan dari gula darah maka akan menjadi acetyl-CoA dan diubah menjadi malonyl-CoA sehingga akan membentuk asam lemak bebas yang akan disimpan dalam bentuk trigliserida[25]. Selanjutnya, kosentrasi trigliserida plasma yang tinggi dapat meningkatkannya ke LDL dan HDL, kemudian secara bersamaan akan mengakibatkan kolesterol ester mengalami proses penukaran dari LDL dan HDL menjadi trigliserida, reaksi yang terjadi tersebut diperantarai oleh CETP atau Cholesterol Ester Transfer Protein ${ }^{[26]}$. Diet tinggi karbohidrat pada pasien dengan penyakit kardiovaskuler berdampak terhadap penurunan kadar kolesterol, HDL dan trigliserida melalui penghambatan proses kerja enzim jenis Lecithin Cholesterol Acyltransferase atau LCAT serta dapat menurunkan komponen protein utama yang disebut sebagai Apo-lipoprotein A1 (Apo A1). Oleh karena itu, kolesterol HDL yang semakin tinggi maka akan menyebabkan proteksi yang tinggi pada oksidasi LDL ${ }^{[2]}$. Dengan demikian, meningkatkan pemahaman pasien PJK terkait asupan karbohidrat dan asupan lemak tentang ketidakseimbangan konsumsi mampu menurunkan kadar kolesterol, LDL, trigliserida serta meningkatkan kadar HDL.

Materi selanjutnya yang disampaikan oleh konselor dalam konseling gizi yaitu terkait dengan aktivitas fisik. Saat ini tingginya angka kematian adalah akibat dari penyakit 
kardiovaskuler, perubahan gaya hidup dan kurangnya aktivitas fisik serta faktor stres memungkinkan sebagai faktor risiko ${ }^{[28]}$. Oleh karena itu, materi aktivitas fisik penting disampaikan dalam konseling gizi untuk penderita PJK yang dirawat jalan terkait pengaruh aktivitas fisik terhadap profil lipid. Selain asupan makanan, faktor aktivitas fisik dapat mempengaruhi kolesterol dalam darah ${ }^{[29]}$. Olah raga yang baik serta teratur sangat bagus dalam menurunkan profil lipid darah, dan meningkatkan kadar HDL pasien PJK ${ }^{[30]}$. Tidak adanya aktifitas fisik yang baik atau tingginya faktor sedentary, dianggap sebagai faktor risiko terhadap penyakit kardiovaskuler. Olah raga teratur dapat meningkatkan komposisi tubuh serta menurunkan permintaan oksigen miokard dan sangat bermanfaat terhadap kardiovaskuler, serta berdampak terhadap rendahnya angka kematian ${ }^{[31]}$.

Kurangnya aktivitas fisik memungkinkan risiko sebesar 7,8 kali terhadap ketidaknormalan profil lipid dalam darah pada penderita kardiovaskuler dibandingkan yang mempunyai aktivitas fisik yang baik ${ }^{[32]}$. Aktivitas fisik dapat meningkatkan kolesterol HDL dan hal ini dapat menurunkan faktor risiko penyakit jantung koroner. Selain itu juga aktifitas fisik dapat menurunkan berat badan akibat penumpukan lemak secara berlebihan (tidak ideal) dan penurunan ini secara bersamaan akan menurunkan kadar kolesterol LDL ${ }^{[33]}$. Dalam konseling ini, aktivitas fisik yang disarankan oleh konselor disesuaikan dengan kondisi pasien. Secara umum bentuk aktivitas fisik untuk mengendalikan berat badan diarahkan pada aktivitas yang sedang. Keteraturan dalam melakukan aerobik minimal sebanyak 3 kali per minggu dengan durasi lebih kurang 30 menit, melalui intensitas yang sedang maka dapat memperbaiki proses metabolisme lemak dalam tubuh. Latihan tersebut seperti bermain sepeda, berlari, jogging, jalan dan atau jalan cepat serta memungkin untuk melakukan renang[16].

\section{Kesimpulan}

Intervensi gizi secara spesifik yaitu melalui konseling gizi menggunakan media leaflet sangat bermanfaat dalam mengubah profil lipid dalam darah, yaitu dapat menurunkan kadar kolesterol, kadar LDL (Low Density Lipoproteins), dan kadar trigliserida serta meningkatkan kadar HDL (High Density Lipoprotein) pada pasien dengan penyakit jantung koroner (PJK) di Kota Banda Aceh.

Perlu diupayakan pengaturan pola makan yang sehat serta olah raga secara teratur dan efektif kepada pasien penyakit jantung koroner. Penyusunan media secara audio visual serta menggunakan jaringan online terkait asupan zat gizi dan aktivitas sangat penting dilakukan dalam upaya edukasi diet kepada pasien Penyakit Jantung Koroner (PJK). Selain itu, perlu dilakukan penelitian lanjutan dengan menambahkan beberapa variabel seperti asupan zat gizi, aktivitas fisik, status gizi serta melibatkan kelompok perlakuan dan kontrol dengan menggunakan desain yang berbeda.

\section{Referensi}

1 C. J. McAloon et al., "The changing face of cardiovascular disease 2000-2012: An analysis of the world health organisation global health estimates data," Int. J. Cardiol., vol. 224, no. 1 December 2016, pp. 256-264, 2016.

2 G. Alicandro et al., "The main causes of death contributing to absolute and relative socioeconomic inequality in Italy," Public Health, vol. 164, no. November 2018, pp. 39-48, 2018.

3 L. Ghani, M. D. Susilawati, and H. Novriani, "Faktor risiko dominan penyakit jantung koroner di Indonesia," Bul. Penelit. Kesehat., vol. 44, no. 3, pp. 153-164, 2016.

4 N. S. Mulyani, A. H. Al Rahmad, and R. Jannah, “Faktor resiko kadar kolesterol darah pada 
pasien rawat jalan penderita jantung koroner di RSUD Meuraxa," AcTion Aceh Nutr. J., vol. 3, no. 2, pp. 132-140, 2018.

5 S. S. Gidding et al., "Pathobiological determinants of atherosclerosis in youth (PDAY) risk score in young adults predicts coronary artery and abdominal aorta calcium in middle age: the CARDIA study," Circulation, vol. 133, no. 2, pp. 139-146, 2016.

Z. N. Hatmi, S. Tahvildari, A. G. Motlag, and A. S. Kashani, "Prevalence of coronary artery disease risk factors in Iran: a population based survey," BMC Cardiovasc. Disord., vol. 7, no. 1, p. 32, 2007.

K. Fujihara et al., "Impact of body mass index and metabolic phenotypes on coronary artery disease according to glucose tolerance status," Diabetes Metab., vol. 43, no. 6, pp. 543-546, 2017.

A. C. Rahmawati, S. Zulaekah, and S. Rahmawaty, "Aktivitas fisik dan rasio kolesterol (HDL) pada penderita penyakit jantung koroner di poliklinik jantung RSUD Dr Moewardi Surakarta," Publ. Ilm., vol. 2, no. 1, pp. 11-18, 2009.

R. W. Utami, S. N. Sofia, and E. A. Murbawani, "Hubungan antara asupan karbohidrat dengan profil lipid pada pasien penyakit jantung koroner," J. Kedokt. Diponegoro, vol. 6, no. 2, pp. 1143-1155, 2017.

10 A. H. Al-Rahmad, A. Annaria, and T. K. Fadjri, "Faktor Resiko Peningkatan Kolesterol pada Usia Diatas 30 Tahun di Kota Banda Aceh," J. Nutr., vol. 18, no. 2, pp. 109-114, 2016.

E. Yuliantini, A. P. Sari, and E. Nur, "Hubungan Asupan Energi, Lemak dan Serat dengan Rasio Kadar Kolesterol Total-HDL," Nutr. Food Res., vol. 38, no. 2, pp. 139-147, 2015.

12 A. H. Al Rahmad, "Pengaruh Pemberian Konseling Gizi terhadap Penurunan Kadar Kolesterol Darah," J. Kesehat., vol. 9, no. 2, pp. 241-247, 2018.

13 L. Dick, "Nutrition Counseling and Education Skill Development," J. Nutr. Educ. Behav., vol. 45, no. 4, pp. 383-e3, 2013.

14 D. P. Sukraniti and I. W. Ambartana, "Pengaruh Konseling Gizi terhadap Perubahan Kadar Gula Darah Berdasarkan Pengetahuan dan Kepatuhan Diet Penderita Diabetes Melitus di Poliklinik Gizi RSUD Kabupaten Karangasem," J Ilmu Gizi, vol. 2, no. 2, pp. 100-108, 2011.

15 R. Feryadi, D. Sulastri, and H. Kadri, "Hubungan kadar profil lipid dengan kejadian hipertensi pada masyarakat etnik Minangkabau di kota Padang tahun 2012," J. Kesehat. Andalas, vol. 3, no. 2, pp. 1-6, 2014.

16 I. Iskandar, A. Hadi, and A. Alfridsyah, “Faktor Risiko Terjadinya Penyakit Jantung Koroner pada Pasien Rumah Sakit Umum Meuraxa Banda Aceh," AcTion Aceh Nutr. J., vol. 2, no. 1, pp. 32-42, 2017.

17 S. Sudikno, H. Syarief, C. M. Dwiriani, H. Riyadi, and J. Pradono, "Hubungan Obesitas Sentral dengan Profil Lipid pada Orang Dewasa Umur 25-65 tahun di Kota Bogor (Baseline Studi Penyakit Tidak Menular di Kota Bogor, Jawa Barat)," Gizi Indones., vol. 39, no. 2, pp. 81-92, 2017.

18 S. F. Zuhroiyyah, H. Sukandar, and S. B. Sastradinanja, “Hubungan Aktivitas Fisik dengan Kadar Kolesterol Total, Kolesterol Low-Density Lipoprotein, dan Kolesterol High-Density Lipoprotein pada Masyarakat Jatinangor," J. Sist. Kesehat., vol. 2, no. 3, pp. 116-122, 2017.

19 R. B. Singh, M. A. Niaz, R. Beegom, G. S. Wander, A. S. Thakur, and H. S. Rissam, “Body fat percent by bioelectrical impedance analysis and risk of coronary artery disease among urban men with low rates of obesity: the Indian paradox," J. Am. Coll. Nutr., vol. 18, no. 3, pp. 268273, 1999.

20 R. G. Aurora, A. Sinambela, and C. H. Noviyanti, “Peran konseling berkelanjutan pada penanganan pasien hiperkolesterolemia," J Indon Med Assoc, vol. 62, no. 5, pp. 194-201, 2012.

21 N. Bhattarai, A. T. Prevost, A. J. Wright, J. Charlton, C. Rudisill, and M. C. Gulliford, 
"Effectiveness of interventions to promote healthy diet in primary care: systematic review and meta-analysis of randomised controlled trials," BMC Public Health, vol. 13, no. 1, p. 1203, 2013.

22 E. Yuliantini and T. C. Maigoda, "Impact Of Sports And Nutrition Counseling To Blood Pressure And Nutritional Status Based On Waist Circumference In Hypertensive Patients At Bengkulu Municipality," Bul. Penelit. Sist. Kesehat., vol. 14, no. 3, pp. 241-247, 2011.

23 A. H. AL Rahmad and A. Miko, "Peningkatan Pengetahuan Calon Pengantin Melalui Konseling ASI Eksklusif di Aceh Besar," Bul. Penelit. Kesehat., vol. 45, no. 4, pp. 249-256, Dec. 2017.

24 G. Harriman et al., "Acetyl-CoA carboxylase inhibition by ND-630 reduces hepatic steatosis, improves insulin sensitivity, and modulates dyslipidemia in rats," Proc. Natl. Acad. Sci., vol. 113, no. 13, pp. E1796-E1805, 2016.

25 S. J. Wakil and L. A. Abu-Elheiga, "Fatty acid metabolism: target for metabolic syndrome," J. Lipid Res., vol. 50, no. Supplement, pp. S138-S143, 2009.

26 E. L. Jim, “Metabolisme lipoprotein,” J. Biomedik JBM, vol. 5, no. 3, pp. 149-156, 2013.

27 A. Levin et al., "Cardiovascular disease in patients with chronic kidney disease: getting to the heart of the matter," Am. J. kidney Dis., vol. 38, no. 6, pp. 1398-1407, 2001.

28 T. Waloya and N. Andarwulan, "Hubungan antara konsumsi pangan dan aktivitas fisik dengan kadar kolesterol darah pria dan wanita dewasa di Bogor," J. Gizi dan Pangan, vol. 8, no. 1, p. 9, 2013.

29 L. Mahan and S. Escott-Stump, Krause's Food \& Nutrition Therapy: 12th Edition, 12th ed. Missouri: Saunders Elsevier, 2008.

30 S. A. H. Shirazi, "Effect of exercise on plasma cholesterol," Gomal J. Med. Sci., vol. 4, no. 2, pp. 70-73, 2006.

31 T. E. Strandberg, L. Kolehmainen, and A. Vuorio, "Evaluation and treatment of older patients with hypercholesterolemia: a clinical review," Jama, vol. 312, no. 11, pp. 1136-1144, 2014.

32 U. F. S. Sunu, G. Permadi, and F. Fenty, "Hubungan Antara Aktivitas Fisik Dan Angka Kecukupan Gizi Makronutrien Terhadap Rasio Kolesterol Total/hdl Pada Masyarakat Pedesaan," J. Pharm. Sci. Community, vol. 14, no. 1, pp. 15-24, 2017.

33 M. A. Delavar, M. S. Lye, S. Hassan, G. L. Khor, and P. Hanachi, "Physical activity, nutrition, and dyslipidemia in middle-aged women," Iran. J. Public Health, vol. 40, no. 4, p. 89, 2011. 